\title{
Politicization of wastewater overflows: The case of the Vantaa River, Finland
}

\section{Heikkinen, Milja Elina}

2016-12

Heikkinen , M E , Schönach , P M \& Massa , I K 2016 , ' Politicization of wastewater overflows: The case of the Vantaa River, Finland ', Water policy, vol. 18 , no. 6 , pp. 1454-1472 . https://doi.org/10.2166/wp.2016.011

http://hdl.handle.net/10138/187724

https://doi.org/10.2166/wp.2016.011

Downloaded from Helda, University of Helsinki institutional repository.

This is an electronic reprint of the original article.

This reprint may differ from the original in pagination and typographic detail.

Please cite the original version. 
This is a pre-copy-editing, author-produced PDF of an article accepted following peer review for publication in Water Policy, Vol 18 (2016): 1454-1472.

The definitive publisher-authenticated version is available online, doi: $10.2166 / \mathrm{wp} .2016 .011$

\title{
Politicization of wastewater overflows: The case of the Vantaa River, Finland
}

\author{
Milja Heikkinen ${ }^{1}$, Paula Schönach ${ }^{1,2}$, Ilmo Massa $^{1}$ \\ ${ }^{1}$ Department of Environmental Sciences, P.O. Box 65, FIN-00014 University of Helsinki, Finland \\ ${ }^{2}$ Corresponding author: paula.schonach@helsinki.fi
}

\begin{abstract}
Here, we analyze the construction and politicization of the environmental problems created by the urban wastewater overflows in the area of the Vantaa River, Finland, between 2004 and 2015. The contradictory uses and values of the river as a wastewater channel and important recreational haven with widely acclaimed ecological values forms the context of this case study. We investigate what types of environmental problem are caused by urban wastewater overflows, how the various stakeholders define the problem, and possible solutions to it. The analysis is based on written materials produced by individuals associated with the problem, applying the method of content analysis. We identify various stages in the evolution of the problem and suggest ways in which cooperation between stakeholders can be enhanced to minimize environmental damage and social harm. These include formulating a common goal, improved mutual information sharing, realistic and clearly communicated plans for technological improvements, and a common understanding of the timescales used for the anticipated results.
\end{abstract}

Keywords | Case study; Construction of environmental problems; Cooperation; Finland; Politicization; Vantaa River; Wastewater overflows

\section{List of abbreviations:}

BAU $=$ Business-as-usual

$\mathrm{CSO}=$ Combined sewer overflow

Eduskunta $=$ Parliament of Finland

$\mathrm{EU}=$ European Union

HS = Helsingin Sanomat (newspaper) 
HSY = Helsinki Region Environmental Services Authority

$\mathrm{HU}=$ Helsingin Uutiset (newspaper)

MP $=$ Member of Parliament

NGO = Non-governmental organization

$\mathrm{SSO}=$ Sanitary system overflow

VHVSY $=$ Water Protection Association of the Vantaa River and Helsinki Region

Virho = Association for Stream Care (Environmental NGO)

$\mathrm{VS}=$ Vantaan Sanomat (newspaper)

WWTP $=$ Wastewater treatment plant

Yle News $=$ Finland's national broadcasting company

\section{INTRODUCTION}

Here, we examine the construction and politicization of wastewater overflows as an environmental problem. Wastewater overflows are unpredictable and stochastic incidents that challenge our perceptions of reliable and extensive basic infrastructures, such as sewerage and wastewater treatment. Along with the maturing wastewater infrastructure during the last century, sanitary services have become a normalized and standardized background process that operates unnoticed, is largely invisible, socially ignored, and taken for granted, unless confronted with a breakdown and functional flaw (Bowker \& Star, 1998; Graham \& Marvin, 2001). Wastewater overflows are such cases of exceptions in the functioning of the wastewater infrastructure.

An overflow occurs when non-purified wastewater either accidentally exits or is intentionally eliminated from the wastewater treatment system and led unpurified into the receiving body of water. Combined sewer overflows (CSOs) are usually caused by sudden flows of excessive water into the wastewater treatment system that exceed the capacity of the system (Metcalf \& Eddy Inc., 2003). This occurs mainly due to heavy rains and melting snow (Tibbetts, 2005). Sanitary system overflows (SSOs) can be caused by entrance of stormwater or technical defects, such as blockages, disruptions in pumping operations, or structural and mechanical failures (Metcalf \& Eddy Inc., 2003). Both CSOs and SSOs cause harmful effects in the environment. ${ }^{1}$

The aim of intentionally performed overflows is to prevent uncontrolled flooding, especially in urban areas (e.g. Tibbetts, 2005). However, extensive improvements in wastewater treatment systems during recent decades have resulted in the acknowledgement that wastewater overflows are considerable sources of pollution in receiving water systems (Lau et al., 2002; Metcalf \& Eddy Inc., 2003). Overflow problems are internationally significant, since similar drainage systems across the developed world face severe challenges, due to increasing urbanization, under-designed wastewater treatment systems, and climate change, which is expected to increase and intensify

\footnotetext{
${ }^{1}$ In this study, we don't differentiate between CSOs and SSOs, even though their environmental impacts vary considerably, due to different dilutive circumstances.
} 
rainfall (Semadeni-Davies et al., 2007; Nie et al., 2009; Heinonen et al., 2013). The future overflow problem is likely to be more significant. Within the European context, societal pressure to enhance water protection is high, and since 2000, the European Union (EU) Water Framework Directive has obliged member states to achieve "good ecological status" of surface waters, including rivers. Wastewater overflows are subject to intensive technical, engineering, and water-quality research. However, we are not aware of previous studies focusing on the overflows as a socially constructed and politicized environmental problem.

Both the risk of unintentional overflows due to technical flaws and the option for intentional and controlled wastewater overflows due to the capacity limits of systems have been designed and purposefully built into wastewater treatment systems (e.g. Tibbetts, 2005). Overflows occur and have always occurred as unforeseen and irregular, but not surprising, events. However, the overflows that have for decades occurred without public attention and criticism, rather unnoticed and as "business-as-usual" (BAU) procedures, have now become the targets of heavy public criticism and a seemingly unaccepted convention. This has led to tensions between the various stakeholders, such as representatives of wastewater treatment services and recreational users.

Here, we investigate how the normalized, but occasional, occurrence of wastewater overflows became a contested and politicized environmental problem and how the tension between stakeholders could be reduced. Our underlying premise in the study is that wastewater overflows cannot be considered as straightforward technical problems to be solved by mere engineering operations. The prevention of wastewater overflows can never succeed completely, which makes it imperative to investigate the societal frames and processes in which overflows are constructed as harmful environmental problems. Hence, constructive suggestions can also be made about how to improve overflow management and alleviate the politicized struggle among the various stakeholders.

The research is based on a case study of a waterbody located in southern Finland, the Vantaa River. It covers the time period 2004-2015. By examination of the different ways the various stakeholders define and interpret the problem, we seek to increase the understanding of the process of constructing and politicizing. We also analyze how disputes over environmental problems related to wastewater overflows could be reduced or solved, based on experience from the Vantaa River case. The article proceeds with an introduction of the analytical framework of our analysis, followed by a description of our case site, and eventually the materials and methods. Later, we present five key findings of our study and discuss them together with some practical recommendations.

\section{Politicization of environmental problems}

Following the contextual constructivist approach to environmental problems, we acknowledge the actual changes that have occurred in the physical environment, but simultaneously base our inquiry on the viewpoint that these changes in the physical environment are constructed as environmental problems through societal negotiation and interpretation (Jones, 2002; Hannigan, 2006). Even if some change in the environment is constructed as a problem, it is not necessarily politicized. A topic is politicized when it evokes claims and becomes an object of public debate (e.g. Hannigan, 2006; Häikiö \& Leino, 2014). There are also other ways to define politicization, but here it is defined simply as the act of opening, broadening, and restoring public discussion (Pellizzoni, 2011). In a model 
developed by Hannigan (2006), the construction of an environmental problem follows a three-phase process: assembling, presenting, and contesting environmental claims. We have applied this model as an analytical framework in our case study (e.g. Ragin, 1994).

Scientific evidence is of crucial importance in constructing environmental problems (e.g. Hannigan, 2006; Pellizzoni, 2011). It forms the basis of the assembly phase (Hannigan, 2006). Nevertheless, as Yearley (2002) pointed out, the problems that seem to be most important by scientific evidence are not always those that gain the most attention. This suggests that there are also mechanisms other than the actual state of the environment that affect the rise of environmental concern.

Public discussion occurs mainly in the mass media, which gives it a significant role in the construction and politicization of environmental issues (e.g. Laine \& Peltonen, 2003; Gavin, 2009), especially in the claim presenting phase (Hannigan, 2006). Opinion trends in society can be initiated in or through the media, although they find final political representation only through and in political organizations (Mazzoleni \& Schulz, 1999). It is important to remember that the target of the media is not to protect the environment, but to sell the news (e.g. Yearley, 2002). This means that the media does not report on environmental issues of little general interest.

If society is convinced that a problem exists and it needs a solution, there will be a contest about how the problem should be solved. At this phase, it is important to develop technical expertise and create functioning networks between the parties related to the problem. It is also important to find ways to open new policy windows. Cooptation, issue fatigue, and countervailing claims can still rule out solving of the problem. The process is not necessarily linear and can be interrupted at any phase (Hannigan, 2006). During the study period, our case was mainly in the phases of claims presenting and contesting, as will be seen.

\section{Empirical context of Vantaa River, southern Finland}

Our study was performed in the empirical context of the Vantaa River, a roughly 100-km-long river in southern Finland (see Fig. 1). It drains into the Baltic Sea at Vanhankaupunginlahti Bay, approximately $6 \mathrm{~km}$ northeast of the city center of Helsinki. The source of the river is in Lake Lallujärvi in the municipality of Hausjärvi.

The average flow of the Vantaa River is a modest $16 \mathrm{~m}^{3} / \mathrm{s}$, but the scarcity of lakes (only $2 \%$ of the basin) in the region increases fluctuations in the river flow. During spring floods, it peaks at $300 \mathrm{~m}^{3} / \mathrm{s}$, but may drop to a mere $2 \mathrm{~m}^{3} / \mathrm{s}$ during the summer months. The river's watershed (1686 $\mathrm{km}^{2}$ ) encompasses, at least partly, the jurisdiction of 14 municipalities with a total of more than one million people. This is roughly $20 \%$ of the entire population of Finland. The Vantaa River is located in the most densely populated parts of the country. The southern part of the catchment is especially urbanized, but apart from communal centers, agricultural lands and forests predominate in the northern parts of the catchment. 


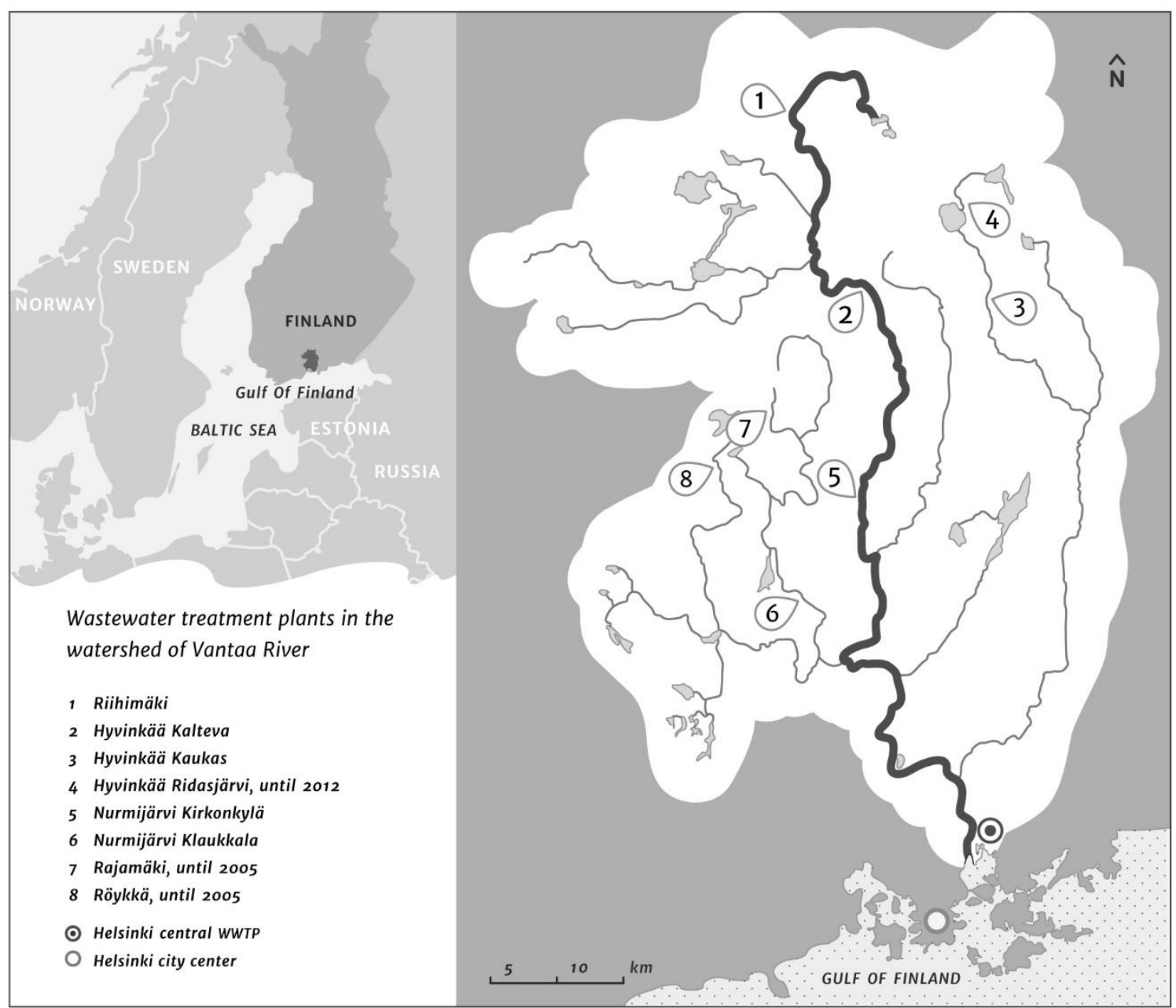

Figure 1. Vantaa River (dark color), its tributaries, and the watershed. Numbered bullets denote the watersheds' wastewater treatment plants (WWTPs), i.e. the main sources for overflows into the river. Purified wastewaters from the Helsinki central treatment plant are discharged into the Gulf of Finland.

Since the late $19^{\text {th }}$ century, the water quality of the Vantaa River has been degraded, especially during the 1960s and 1970s, when municipal and industrial wastewaters polluted it heavily and improvements in wastewater treatment were not yet effective (Schönach, 2015). Since the 1980s, continual progress has been made in decreasing wastewater loading into the Vantaa River, both in terms of quantity and quality. Communal sanitation infrastructural coverage has been extended, existing treatment facilities have been upgraded and, most importantly, an extensive pumping network was finalized in 1987 in the northeastern parts of the catchment. During the study period, the number of wastewater treatment plants (WWTPs) discharging into the Vantaa River has decreased from eight to five because wastewaters have been conveyed to the central WWTP in Helsinki for treatment. These treated wastewaters are discharged into the Gulf of Finland, hence decreasing pressure on the river. However, several WWTPs serving the municipalities in the northern parts of the catchment still drain the purified wastewaters into the river (see Fig. 1). Our study covers the years 2004-2014 and the first 6 months of 2015 . 
Currently, the river water quality is moderate according to classification defined in the EU Water Framework Directive (Vahtera et al., 2014). To meet the extended aims of the EU Water Framework Directive, including a good ecological status by 2015 and subsequently by 2021, considerable improvements are still required in the Vantaa River (Vahtera et al., 2010). The Vantaa River also serves as the secondary and emergency freshwater source for the Helsinki region, Lake Päijänne in Central Finland being the main source. Due to this function, the water quality of the river is of critical importance under exceptional conditions (e.g. in 2008, see Results and Discussion).

The waterway system of the Vantaa River is an important recreational area. It has widely acclaimed ecological and cultural/historical value, and several parts of it have been declared nature protection areas, including 17 areas that form part of the Pan-European Natura 2000 network. Improvement in the previously degraded water quality has increased its recreational value and revitalized fishing opportunities. The first fish ladder was built at the river mouth in 1986, and since 1996 restoration efforts, especially for improved migrant fish reproduction, have been carried out at a cost of more than 1 million euros. In 2012, a total of 6621 fishing licenses were granted for the area (Haikonen et al., 2013; www.vantaanjoki.com). Since the river is important for a highly populated region, its water quality is in the interest of various stakeholders.

\section{MATERIALS AND METHODS}

To investigate our research questions, we applied the case study as our research strategy. It aims at detailed, intensive knowledge about a single case that illuminated the phenomenon under scrutiny and was investigated within its real-life context (Yin, 2003). Case-study research is typically based on several types of material.

To trace back the process of environmental problem construction, we collected documentary material produced by the stakeholders of the case and comprehensive media material. The documentary material included reports, bulletins, statements, and inquiries on the subject in the Parliament of Finland (Eduskunta). We analyzed annually published statutory environmental monitoring reports, independent studies commissioned by stakeholders, and research conducted by national research institutes. The most important stakeholders include the environmental nongovernmental organization (NGO) Association for Stream Care (Virtavesien hoitoyhdistys, Virho), which focuses especially on fishery issues and the Water Protection Association of the Vantaa River and Helsinki Region (Vantaanjoen ja Helsingin seudun vesiensuojeluyhdistys, VHVSY), a broad based association with members representing municipal and commercial interests, and various nonprofit NGOs. We also analyzed reports by various consulting firms and the Helsinki Region Environmental Services Authority (Helsingin Seudun ympäristöpalvelut, HSY), responsible for water and waste-management services and regional and environmental information services. The Members of Parliament (MPs) drew up three written questions and one proposal for action. These were also included in the analyses.

The other major source consisted of media material from the main newspaper of Finland, Helsingin Sanomat (HS), and from the national broadcasting company's (Yle News) news service, including public commentaries on the respective articles. Articles were also collected from 
the local newspapers Vantaan Sanomat (VS) and Helsingin Uutiset (HU). Only articles that discussed the overflow question more than briefly, numbering 69 in total, were included in the material.

The analysis was initiated with a chronological and detailed description of the case and the evolution of public debate on the wastewater overflows. Based on this material, we created a chronological description of the conversation. This was done by organizing the material in a table. We marked who had published the material and when, what the main information was on the overflow problem, and whose point of view was presented. Thereafter, we analyzed the material more thoroughly, using qualitative content analysis (e.g. Krippendorff \& Bock, 2009) and within the analytical framework of the construction process of the environmental problems. We focused especially on the various stakeholders' standpoints and how they evolved during the study period. We reflected the evolution of the debate on the model of Hannigan (2006).

\section{RESULTS AND DISCUSSION}

The temporal starting point of our research was the year 2004. During the summer of that year, exceptionally large wastewater overflows were reported in association with summer floods. Extensive fish die-offs occurred in the river and there was debate over who was responsible. In 2008, the Vantaa River and its water quality were the objects of increased public scrutiny. Due to some renovation work in the primary water-supply aqueduct, for 9 months the river served as the freshwater source for the entire Helsinki region. In terms of overflows, the next critical year was 2010, when again exceptionally large overflows occurred. The overflow debate was brought out at the national level and also discussed in Parliament, while polarized debate over the discharges was led in public.

Media coverage of the overflow episodes during the study period varied strongly. As presented in Figure 2, the media focus tended to follow the amount of emissions, but it did not follow them directly. In some years, the news coverage decreased, although the emissions increased. This may have resulted from the discharges not being large enough to provoke public outrage; this was probably the case during 2006 and 2007. The emissions may also have lost their news value very rapidly, which was probably the case in 2011. This reflects on Yearley (2002), who pointed out that the media wants stories that sell easily in the media market, and continuing bad practice does not sell. If it is not possible to find a new point of view, the topic loses its novelty, which has been identified as one of the key pitfalls in the claims presenting phase of environmental problem construction (Hannigan, 2006). This suggests that news coverage may follow more the change in emission amounts rather than the absolute amount of emissions. 


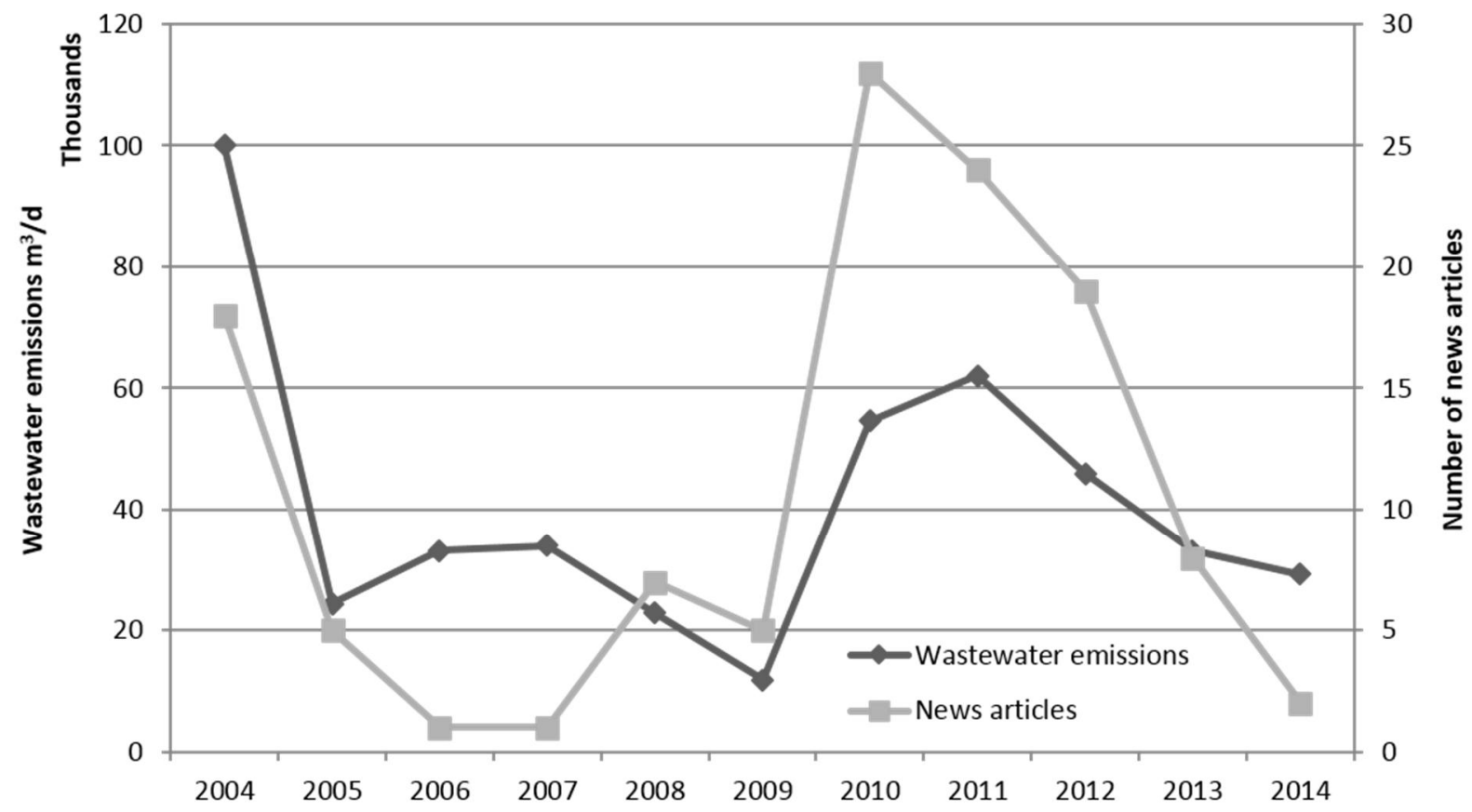

Figure 2. Wastewater overflows to the Vantaa River and the number of news articles reporting the overflow incidents during 2004-2014.

Based on activity in producing materials and appearance in the media data, the key stakeholders of the case were the municipal waterworks and their representatives, community and state officials, and NGOs. Some individual politicians and private persons were also active in the debates. The officials played a major role, which is in line with previous studies concerning public discussion on environmental problems in Finland (Väliverronen, 1997). The stakeholders were divided into two groups: NGOs, some communal officials, some politicians, and private persons strongly criticizing the overflows (the critical group) and some officials, some politicians, and representatives of WWTPs contesting the criticism (the BAU group). The most active stakeholders remained the same during the study period.

We determined that effects of the overflows most discussed were the possible injuries caused to fish and to the recreational use of the river. The debate over effects of the overflows mainly reflected the claims presenting phase in the model of Hannigan (2006), but there were also issues related to the assembly phase. Other important themes included technology, money, and workings of the wastewater treatment organizations and officials. The debate over these themes reflected more the contesting phase of Hannigan's model. Towards the end of the study period, a settling of the debate was observed, although no clear solution was found to the overflow problem.

\section{Scientific controversy weakens the basis of the problem}

The main ecological problems caused by wastewater overflows are eutrophication and hypoxia. Our materials showed that hypoxia is considered more significant in the Vantaa River, because 
eutrophication is largely caused by scattered loading (non-point source pollution) (e.g. Vahtera et al., 2014). Nevertheless, the relationship between cause and effect is not always clear. This leads to a situation in which the scientific basis of the claim against overflows is controversial.

Usually, hypoxia affects the river only for limited durations; however, it can still be lethal for organisms or disturb reproduction. In the Vantaa River, the possibilities of fish mortality and problems in spawning have become the objects of increased focus, because there are numerous active fishermen in the region. Both Virho and officials have worked hard to better the living conditions of fish in the river.

Fish mortality was one of the main news topics in the first study year in 2004. After the summer floods, the fish stocks in the river collapsed. At first, the wastewater overflows were blamed (Yle News 12.8.2004; HS 13.8.2004). The regional fisheries authority demanded that cities should compensate them for the resources they had used to restore the fish stocks (HS 14.8.2004a; Yle News 14.8.2004), but the cities refuted their responsibility, arguing that there was no way to prevent the overflows (HS 14.8.2004b). The regional environment centers also argued that the real reason for the oxygen depletion was the scattered loading, which also increased during the floods. (HS 20.8.2004; Vahtera et al., 2005). No compensation was paid, and consensus about the reason for the hypoxia was not reached. Officially, it was announced that both overflows and scattered loading caused the hypoxia (Uusimaa Employment and Economic Development Center \& VHVSY, 2004; Saura et al., 2005). However, VHVSY emphasized the scattered loading (Vahtera et al., 2005), while Virho stuck with the argument that the main reason was the overflows, but that their influence was underestimated on purpose by the officials (Stenholm, 2004; Stenholm \& Lehtinen, 2005). This resulted in communicative tension between the parties that was still discernible after 10 years (HS 1.6.2014).

Fish mortality was mentioned in the media data every year between 2008 and 2012. Still, there was no fish mortality case in which it could be proved that the main reason was wastewater overflows. In July 2010, there was a case in which all the fish from a certain part of the river near the Riihimäki WWTP died, but contrasting views about the reasons prevailed (Yle News 12.7.2010; HS 20.7.2010). The critical group insisted on the view that the fish die-offs caused by the wastewater were one of the worst problems of the river (e.g. Stenholm \& Lehtinen, 2005; Stenholm, 2006, 2012). One official from the regional environmental center even said that the oxygen depletions and fish dieoffs were continuous, due to the regular overflows (Yle News 3.10.2009). However, in the reports produced by VHVSY and the Finnish Game and Fisheries Research Institute, the fish die-offs did not appear continuously. This shows that there was contradictory information even among the officials.

Research reports of the impacts of the wastewater on organisms are contradictory. In some reports, the impact was evaluated as significant (Haikonen et al., 2010), while others tended to consider it of minor significance (Raunio et al., 2009, 2011). On the other hand, the quality of the reports and the methods for investigating the impacts were criticized, both by the NGOs and the officials themselves (Stenholm, 2008; Raunio et al., 2009, 2011; Haikonen et al., 2013). This suggests that improving scientific monitoring is needed for better understanding of the ecological importance of overflows.

The contradictions presented in this chapter weaken the scientific basis of the problem. This is a typical pitfall in the assembly phase of the construction of environmental problems 
(Hannigan, 2006). The lack of proper scientific bases makes it difficult for the public and other stakeholders to construct a view of the severity of the overflow problem. Since there is no shared consensus of the effects caused by overflows, it is difficult to reach a consensus of the responsibilities and rights of the various stakeholders.

\section{Overflows encumber the recreational use of the river}

The problems affecting humans are important justifications for the claims of the critical group. The wastewater overflows decrease the hygienic quality of the river. The low hygienic quality prevents recreational uses of the river, especially swimming, but also canoeing and fishing. The importance of the river as a swimming place stands out, because there are not many lakes in the region. The low hygienic quality also prevents the use of the river water for watering vegetable gardens.

Visible pollution makes it unpleasant to spend time on the riverbanks and visit nature trails. The wastewater overflows harm the image people have of the river. This may cause people to see pollution even when it does not exist; e.g. they may interpret the natural brownish color of the river as a sign of pollution, as was noted in inquiries made to fishermen (e.g. Saura et al., 2005).

Every time overflows occurred during the summer, they triggered questioning of the safety of the river water to swimmers. Officials warned about the insufficient hygienic quality and the related health risks for swimmers during three different summer overflow episodes (HS 3.8.2004, 4.8.2004, 6.8.2004, 14.8.2010; Yle News 13.8.2010, 23.8.2010, 1.6.2011). In 2004, additional waterquality monitoring by environmental officials was introduced, out of concern for swimmers (HS 11.8.2004). Two swimmers were also interviewed in the media. Their reactions reflected the continual nature of environmental change and the multidimensional and temporally shifting perception of these changes by the public. One interviewee was not worried, because in any case the condition of the river was better than before (HS 13.8.2010); the other was worried that her old swimming place would be unusable (Yle News 16.8.2010). Comparison of past recreational possibilities and anticipations of future conditions mark very different approaches to prevailing conditions.

Officials also interpreted the risks related to water quality after overflow episodes differently, and hence contrasting recommendations became public. In the summer of 2010, the VHVSY announced that swimming should be avoided, while the City of Helsinki Environment Centre declared that there was no special risk (Yle News 13.8.2010; HS 14.8.2010). The VHVSY showed that the contradictions were due to varying observation techniques and sampling sites (HS 14.8.2010). This example highlights that "good water quality for swimming" is somewhat arbitrary, despite the use of official monitoring standards and scientific follow-up.

The efficiency of communication about the overflows was also inadequate. Despite continual observation of the quality of the water, a lifeguard at a riverine swimming place claimed that she received no official information about the overflows (HS 13.8.2010). Similarly, Virho claimed that since nobody else cared to inform fishermen about the water quality, Virho should obtain the information about overflows more rapidly (HU 25.7.2013; Stenholm, 2013). Communication 
problems about overflows and related water-quality risks concerned accuracy, timing, extent, and efficiency.

The process shows that scientific proof alone is not sufficient to tackle the problem. In the case of the Vantaa River, a scientific consensus exists that most of the emissions are not a significant threat to human health. Likewise, agricultural emissions pose an overall greater environmental burden to the river than the wastewater overflows. Despite acknowledging this, the critique against the overflows has been strong. Although the discharges into the Vantaa River have recently been much smaller than previously, they have sparked more intense activism and heated debate. The boundaries of acceptability have shifted, with new emphases on environmental values and increasing welfare. Wastewater overflows are not considered acceptable in a society with living standards as high as in Finland. The growing environmental and health-related concerns have also challenged current methods of wastewater treatment in use elsewhere, and it is likely that future pressure will increase (Metcalf \& Eddy Inc., 2003). The mental image of the overflows is already bad enough to harm the recreational values of the river and to make people consider them as a problem. The swimming bans and other signs of overflows reinforce the mental image and decrease the recreational values concretely.

\section{Accusations of technological and financial limits}

The BAU group claims that the grounds for the emergence of an overflow conflict is change in the ways of thinking. According to them, it was previously generally accepted that it is occasionally necessary to release wastewater into rivers and seas, but now public opinion has changed (Urho, 2011; HS 28.4.2013). On the other hand, the awareness of the public about the built-in possibility for deliberate overflows can be questioned. According to the critical group, people have been shocked when learning that overflows are an existing and legal practice (e.g. VS 23.9.2011). If people have never, in effect, understood that the WWTPs - even renovated ones - permit the overflows, they have never consciously accepted it in the first place. It seems, the process is influenced by two overlapping developments: the combination of increasing general awareness and less tolerant opinion of those who are aware of the overflows.

Technological issues were at the core of the argumentation of the BAU group that the unavoidability of overflows should be rationalized. The main problems are the wide variation in influent flow volumes, the outdated or aging technology, the insufficient capacity of the WWTPs to deal with these fluctuations, the combined sewers, and the fact that it is difficult to build sewers that will never leak (e.g. Yle News 11.9.2010, 11.4.2011, 13.11.2012, HS 30.4.2011; Urho, 2011). Representatives of the WWTPs stated that it is not possible to build sewer systems adjusted for flooding periods, because then the systems would not function under normal conditions (e.g. HS 14.8.2004b). A balance between exceptional situations and normal operation is always a compromise.

The technological framework of the problem is highlighted in the statement that the fundamental problem is a sanitation system based on water. Hence, the real solution of the overflow question would need an entirely different infrastructure to be built (HS 1.5.2013). This statement remained singular and exemplifies how preset frameworks of public debate rule out some perspectives as irrational or irrelevant (Mikola \& Häikiö, 2014). The "non-decision making" (cf. 
Jakku et al., 2009) on these ruled-out perspectives are, in this case, excluded through infrastructural path dependency. The solutions to the problem must be in alignment with the currently accepted technological frameworks, while too large a scale of modifications is excluded from the range of possible solutions.

The wastewater treatment infrastructure is one of the most costly construction systems supporting general welfare. Hence, the economic question is always strongly present in the debates. The main argument of the BAU group was that prevention of all overflows is too costly in comparison to the benefits achievable (Eduskunta, 2010b; Yle News 11.4.2011; VS 15.11.2012). It was also suggested that some of the money that should go to the renovation of sewers and WWTPs ends up being used for other purposes, since the communities nearly always have more need for investment than resources to invest (VS 23.9.2011). HSY especially highlighted that they could not do the renovations required if the funding was not secured (Urho, 2011). Communities are constantly confronted with prioritization issues, and the urgency of improvements in wastewater treatment is compared with other needs.

The acting Minister of the Environment demanded that the cities in the Vantaa River watershed should invest more in wastewater treatment (Eduskunta, 2010a, b, c, 2011), but she also admitted the current financial situation is difficult (Yle News 16.8.2010). Her response to a written question at Parliament about the overflow problem stated that it is not possible to stop overflows "without unreasonable costs" (Eduskunta, 2010b). The cities in the upper reaches of the river have historically considered investments in wastewater treatment infrastructure as unproductive, since the main benefits are experienced at the lower reaches (Schönach, 2015). This was also seen in our case, when it was proposed that the negative effects of overflows could be reduced with the extra water from Lake Päijänne. The upper-reach cities rejected the idea as too costly (Yle News 27.8.2010). On the other hand, Helsinki argued that it is unfair that its citizens should bear the brunt of the pollution from the upper-reach cities (Yle News 27.6.2012). The geographic disconnection of the original location of the discharges at the upper-reach WWTPs and the negative environmental consequences downstream complicate the debate about costs, benefits, and responsibilities.

No overall solutions to the technical and financial problems were presented. Nevertheless, the WWTPs are seeking such solutions (HSY, 2014). One effort was the expansion and renewal of the Riihimäki WWTP, which has been most often the source of large emissions. The reconstructed and extended plant began operations in early 2015, and expectant outlooks were expressed over the termination of overflows from Riihimäki during normal spring weather (HS 16.2.2015). However, in the same news article, the representative from the Riihimäki WWTP said that no facility could handle the extraordinary amount of water received in the summer of 2004.

By the end of the study period, the technical questions remained partly unresolved. Some technical improvements have been carried out and others are planned, but there is still no solution that could end the overflows totally. It remains open whether the various stakeholders can find a shared point of view when it comes to the financial side of the issue. At the same time, the stakeholders do not totally agree that the technological and financial problems are the most important reasons behind the overflow problem, as will be shown in the next chapter. 


\section{Accusations of lack of will, cooperation, and open communication}

A crucial factor contributing to the politicization of the overflow problem is the mutual distrust of stakeholders and accusations of insufficient communication. The critical group stated that those in charge of the wastewater treatment care nothing for the ecological and recreational values of the Vantaa River (e.g. Stenholm \& Lehtinen, 2005; Yle News 12.7.2010, 27.8.2010; HS 14.10.2012). Their argument was that the problem could be solved if there was only the will to do so.

The critical group also saw that there was a lack of cooperation and open communication (e.g. Stenholm, 2004, 2013; Stenholm \& Lehtinen, 2005; HS 16.10.2008; Vahtera et al., 2008). Virho even accused the officials of giving false information and systematically covering up the wastewater overflows (Stenholm, 2004, 2008, 2012; Stenholm \& Lehtinen, 2005). Officials declined to respond to the accusation directly, but later the representatives of the WWTPs did highlight that they were willing to cooperate and to improve communication (e.g. HS 20.11.2011). They argued that real-time reporting of overflows is impossible, especially if they happen outside of office hours, due to the lack of staff (Lahti, 2014). Efficient communication requires sufficient resources.

Cooperation increased towards the end of the study period. Finding a common goal was of crucial importance to this process. Nevertheless, to make cooperation function properly, the problems described in this chapter should be considered. It is difficult to see efficient cooperation between stakeholders who are convinced that they have significantly opposing values. Similarly, it is evident that cooperation requires efficient communication.

\section{Evolution from juxtaposition to cooperation}

The problem at the beginning of the study period was discovered and named and a scientific practice established for monitoring. There was some argumentation related to the basis of the problem, because there was no scientific consensus for the effect of overflows. Nevertheless, the debate was mainly about legitimizing the overflows as an environmental problem that needs to be solved and about possible solutions.

The debate was polarized (see Fig. 3). The critical group legitimized their claim that the overflows must be ended, resting their arguments on the ecological and recreational values of the river and on the moral responsibility that we have for our environment. The BAU group tried to make the problem unpolitical, arguing strongly that it was impossible to stop the overflows completely, due to the aforementioned technical and financial problems. The groups had different perceptions of the problem: its causes, communication, and to some extent its solution. 


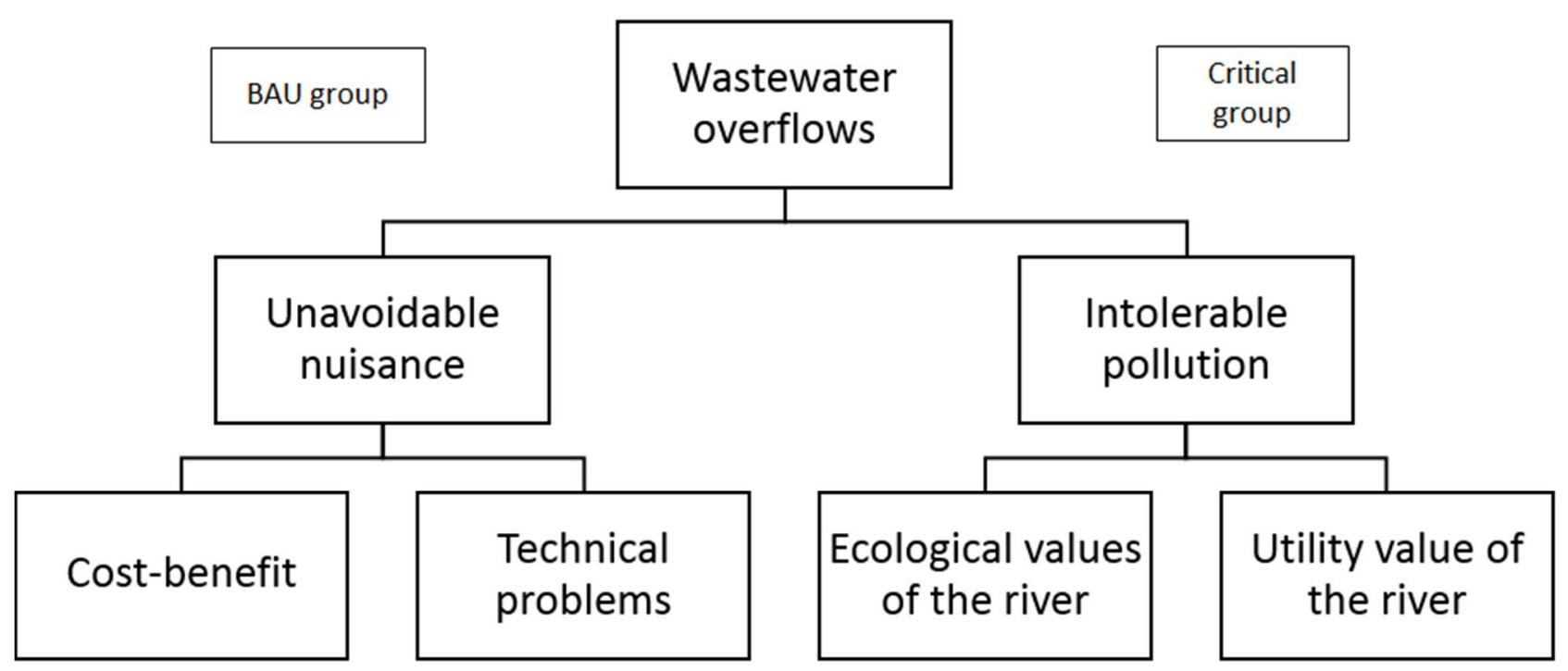

Figure 3. Summary of the stakeholders' divided viewpoints.

The turning point in the debate was reached in 2013, when the waterworks announced that their long-term goal was to terminate wastewater overflows (HSY \& VHVSY, 2013; HU 6.2.2013; HS 28.4.2013). At the same time, the waterworks and officials held the first cooperative meeting with the NGOs. Our material doesn't provide unambiguous explanation for this rather thorough change in target-setting. Increased public attention and pressure combined with the tendency of tightening statutory demands to decrease discharges is a possible explanation. However, since few suggestions of concrete measures to achieve this target have been presented, it could also be seen as a strategic and rhetoric concession to curb the critique from the public. Increased willingness for cooperation together with a surprising and sudden shift in target-setting could suggest that the change was triggered by a combination of these factors. In any case, after this point the wastewater overflows were commonly accepted as an environmental problem that should be solved. The focus then moved to ways of solving the problem.

Cooperation has continued. The second official meeting in 2014 was much more cooperative than the first one in 2013. There were signs of a possible meeting halfway: Virho declared in the spring of 2015 that it was necessary to secure the functioning of the sewage system in as favorable a state as possible during floods (Stenholm, 2015). The claim is not as peremptory as it used to be. The construction process has clearly reached the step in which action is invoked and the central forum of debate turns from mass media into politics (Hannigan, 2006). The problem is now in a state in which it could be solved.

Nevertheless, there is still a lack of concrete plans for solving the problem. Some concrete changes and accounts have been made (e.g. HSY, 2014), but nobody believes that these could totally stop the overflows. Now that a common ambition has been declared, there is a risk that 
the conflict will again be ignited if the parties lack a common view of how the reforms will be brought about. One problem will most probably be the cost of the solution and another the timetable. The parties may not have the same idea of the length of time needed to perform certain renovations or changes. Are a few years sufficient or not to accomplish infrastructural improvements? The relative perception of the duration of change varies according to the different users. Several years of hampered recreational use is a long time, while infrastructural constructions ordinarily require very long time periods. When the City of Helsinki finally decided that all wastewater should be treated, it required 43 years to complete the decision (Laakkonen, 2001). Possible misunderstandings related to these issues could have been avoided through open conversation about the targets and ways to reach them.

\section{Strengthening cooperation can prevent conflicts}

Networking, opening of new policy windows, and developing technical expertise are key elements of success in the contesting phase (Hannigan, 2006). Proper cooperation could lead to win-win situations in the case of the Vantaa River. Another pollution case in Helsinki shows that downplaying lay experience and knowledge in matters of local environment increases confrontation and mistrust (Saikkonen, 2015). In Finland, the method of governance has been described as being more closed than open, which means that traditionally the citizens have not been seen as active subjects (Laine \& Peltonen, 2003). Alternatively, NGOs have the potential to democratize expertise and make knowledge useful (Eden et al., 2006). It could be beneficial to strengthen stakeholder participation in the overflow case.

One aspect that should be considered is the role played by NGOs and private persons as producers of environmental knowledge. There is evidence to suggest that citizens would be capable of participating more than is commonly believed (e.g. Fischer, 2003). Virho especially has several times emphasized their thorough knowledge of the river, its fish populations, and the effects of wastewater overflows. It could be worth trying to encourage them to participate actively in the monitoring process of the river. Information from citizens' cloud services were also taken into account when the renovations of the sewer systems were completed.

While the wastewater infrastructure as a whole and its prospective improvements are the responsibility of the public utilities, the various stakeholders need to be incorporated into the process. The annual cooperation meetings have proved to be a good start. Still, it is important to ensure that the cooperation will not exist only in reports and official comments. In cooperation, all the participants should feel that they can, at least to some extent, influence the situation. Also, it seems that because of the background process kind of operation, currently the public is not well informed when it comes to the normalized practices, technical limitations and legislation. More open dialogue could reduce misunderstandings and excessive expectations.

New, up-to-date, and interactive communication channels could be developed through cooperation. NGOs have valuable experience in a number of areas from fostering new communication channels, e.g. social media such as the Facebook page "Save the Vantaa River" (Pelastakaa Vantaanjoki), to effective and extensive information flow with broad coverage. The new methods of information sharing could also be used to announce the overflows outside office hours. If the activists were able to participate in the meetings of WWTPs and city governments where the concrete 
decisions and plans for solving the problems are initiated, they could inform other interested persons about the progress made. This would make the process more transparent and reduce the mistrust on both sides. It would also make it easier to obtain publicity of the slow progress made in solving the problem, since it is not newsworthy enough in the traditional media and therefore not highlighted. Setting interim targets would help to concretize the path towards the solution.

Open communication also helps stakeholders to form a mutual understanding of the situation. To make cooperation work, it is important that everyone has a shared view on what is going to be done, why, and with which timetable. If the stakeholders have different expectations, the probability of disappointment, frustration, and conflict increases. Without concrete and realistic plans, it may also seem that the announcement of the target of ending the overflows is mainly a way to calm down the critic, not find a real solution.

\section{CONCLUSION}

The case of the Vantaa River shows that an existing wastewater treatment infrastructure is not a final and completed solution working in isolation of society. Even as a societally rather invisible, lowinterest background process, it requires constant developing, technological improvements, and cooperation with several interest groups. The conflict about the wastewater overflows in the region of the Vantaa River is an exemplary case of the phenomenon of previously normalized, established conventions becoming the objects of politicized (environmental) problems.

The overflow problem must be seen as part of the continuum of the river water-quality improvement during the last three decades. Improved environmental quality has promoted more extensive recreational use and substantial investments in river restoration, especially in fish stocks. Summer floods followed by large wastewater overflows in 2004 were discharged into an important local recreational haven, instead of the open sewer-like river of the 1960s. Currently, the wastewater overflows to the Vantaa River are seen as a threat to other uses and values of the river. Hence, they spark debate about the legitimacy of the overflows as a part of the wastewater treatment system.

The evolution of politicized environmental problems is influenced by many simultaneously evolving aspects and societal developments, which underlines the complex, contextbound and temporally fluctuating nature of disputes like our case. Available technological solutions and the related costs necessitate reoccurring economic prioritizations that in turn reflect the valuation of different services at a given time. Within the prevalent contextual frame of increasing living standards, existing comprehensive sanitary infrastructure and the general tendency of tightening statutory demands towards wastewater treatment, the politicization of the overflow problematic increases attention towards curbing them more vigorously.

Increased public awareness about and engagement in the environmental vulnerabilities of sanitary infrastructure, triggered by imposing, yet occasional and short-lived overflow episodes, enhanced through media publicity and new, instant communication channels, generate a new kind of pressure for wastewater authorities to publicly encounter the previously rather low-attention problem. However, a more detailed analysis of the impetuses for change in the goal setting of the wastewater 
authorities towards overflows would require e.g. in-depth interviews of the key stakeholders, and remains a task of future research.

Involvement in coordinated public discussion about the overflows seems to strengthen and accelerate the shift towards solution-oriented cooperation. Hence, the case underlines the benefits of an inclusive communication strategy at an early stage of the process. In our case, the interest groups in this case have continued cooperative meetings after the study period and the results are considered promising (Lahti, 2015). While some questions still await resolution, progress towards a mutually satisfactory direction within a realistic timeframe seems now possible. With the establishment of mutually acceptable guidelines for future developments, the politicized phase of an environmental problem shifts into a more de-politicized stage, at least for the time being.

\section{REFERENCES}

Bowker, G. C. \& Star, S. L. (1998). Building information infrastructures for social worlds: The role of classifications and standards. In: Community Computing and Support Systems. T. Ishida (ed.). Springer, Berlin, Germany, pp. 231-248.

Eden, S., Donaldson A. \& Walker, G. (2006). Green groups and grey areas: scientific boundarywork, nongovernmental organisations, and environmental knowledge. Environment and Planning A, 38(6), 1061-1076.

Eduskunta (2010a). Vantaanjoen jätevesipäästöjen vähentäminen, kirjallinen kysymys 289/2010 vp (Reduction of wastewater emissions to the Vantaa River, written question 289/2010 vp), https://www.eduskunta.fi/FI/vaski/Kysymys/Documents/kk 289+2010.pdf (7.1.2016).

Eduskunta (2010b). Virtaavien vesien tilan parantaminen, kirjallinen kysymys 553/2010 vp (Improving the state of streaming waters, written question 553/2010 vp), https://www.eduskunta.fi/FI/vaski/Kysymys/Documents/kk_553+2010.pdf (7.1.2016).

Eduskunta (2010c). Vantaanjoen veden laadun parantaminen, kirjallinen kysymys 685/2010 vp (Improving the quality of the Vantaa River, written question 685/2010 vp), https://www.eduskunta.fi/FI/Vaski/sivut/trip.aspx?triptype=ValtiopaivaAsiakirjat\&docid=kk $+684 / 2010(7.1 .2016)$.

Eduskunta (2011). Vantaanjoen saastuminen, kirjallinen kysymys 10/2011 vp (Pollution of the Vantaa River, written question 10/2010 vp), https://www.eduskunta.fi/FI/vaski/Kysymys/Documents/kk_10+2011.pdf (7.1.2016).

Fischer, F. (2003). Citizens, Experts, and the Environment. The Politics of Local Knowledge. Duke University Press, London, Great Britain.

Gavin, N. L. (2009). Addressing climate change: a media perspective. Environmental Politics, 18(5), 765-780. DOI: 10.1080/09644010903157081.

Graham, S. \& Marvin, S. (2001). Splintering Urbanism. Networked Infrastructures, Technological Mobilities and the Urban Condition. Routledge, London and New York.

Haikonen, A., Köngäs, P. \& Paasivirta, L. (2010). Vantaanjoen yhteistarkkailu. Pohjaeläimet vuonna 2009 (Cooperative observation of the Vantaa River. Benthos in year 2009), Report Kala- ja vesiraportteja 4, Kala- ja vesitutkimus Oy.

Haikonen, A., Paasivirta, L., Helminen, J. \& Tolvanen O. (2013). Vantaanjoen yhteistarkkailu. Kalasto ja pohjaeläimet vuonna 2012 (Cooperative observation of the Vantaa River. Fish populations and benthos in year 2012), Report Kala- ja vesitutkimuksia nro 105, Kala- ja vesitutkimus $\mathrm{Oy}$.

Hannigan, J. A. (2006). Environmental Sociology. Second Edition, Routledge, London, Great Britain. 
Heinonen, M., Jokelainen, M., Fred, T., Koistinen, J. \& Hohti, H. (2013). Improved wet weather waste water influent modelling at Viikinmäki WWTP by online weather radar information. Water Science \& Technology, 68(3), 499-505.

HS 3.8.2004 Tulvat tekivät vesistä uimakelvottomia (Flooding turns waters unsuitable for swimming)

http://www.hs.fi/paivanlehti/arkisto/Tulvat+tekiv\%C3\%A4t+vesist\%C3\%A4+uimakelvotto mia/aaHS20040803SI1 KA02ti7?src=haku\&ref=arkisto\%2F (7.1.2016).

HS 4.8.2004 Terveystarkastaja varoittaa Helsingin uimavesien laadusta (Health officers warn about quality of swimming waters)

http://www.hs.fi/paivanlehti/arkisto/Terveystarkastaja+varoittaa+Helsingin+uimavesien+laa dusta/aaHS20040804SI1KA02x1a?src=haku\&ref=arkisto\%2F (7.1.2016).

HS 6.8.2004 Helsinki tilaa virustutkimuksen Vantaanjoen tulvavesistä (City of Helsinki orders virus analysis of floodwaters in Vantaa River)

http://www.hs.fi/paivanlehti/arkisto/Helsinki+tilaa+virustutkimuksen+Vantaanjoen+tulvaves ist\%C3\%A4/aaHS20040806SI1 KA020y8?src=haku\&ref=arkisto\%2F (7.1.2016).

HS 11.8.2004 Uimavesiä tutkitaan huolella (Thorough testing of swimming waters) http://www.hs.fi/paivanlehti/arkisto/Uimavesi\%C3\%A4+tutkitaan+huolella/aaHS20040811S I1MP01bso?src=haku\&ref=arkisto\%2F (7.1.2016).

HS 13.8.2004 Vantaanjoen kalat kuolivat 40 kilometrin matkalta (Vantaa River fish died along a 40-km stretch)

http://www.hs.fi/paivanlehti/arkisto/Vantaanjoen+kalat+kuolivat+40+kilometrin+matkalta/a aHS20040813SIKA02h4e?src=haku\&ref=arkisto\%2F (7.1.2016).

HS 14.8.2004a TE-keskukset hakevat korvauksia Vantaanjoen kalakuolemista (TE-centers seeking compensations for fish die-offs in Vantaa River) http://www.hs.fi/paivanlehti/arkisto/TEkeskukset+hakevat+korvauksia+Vantaanjoen+kalakuolemista/aaHS20040814SI1YO02j4t?s $\mathrm{rc}=$ haku\&ref=arkisto\%2F $(7.1 .2016)$.

HS 14.8.2004b Kaupungit kiistävät vastuunsa (Cities deny responsibility) http://www.hs.fi/paivanlehti/arkisto/Kaupungit+kiist\%C3\%A4v\%C3\% A4t+vastuunsa/aaHS 20040814SI1YO02j4q?src=haku\&ref=arkisto\%2F (7.1.2016).

HS 20.8.2004 Ympäristökeskukset: Jätevesillä ei ollut ratkaisevaa osuutta tulvatuhoissa (Regional Environment Centers: Wastewaters did not play key role in flood destruction) http://www.hs.fi/paivanlehti/arkisto/Ymp\%C3\%A4rist\%C3\%B6keskukset+J\%C3\%A4tevesi

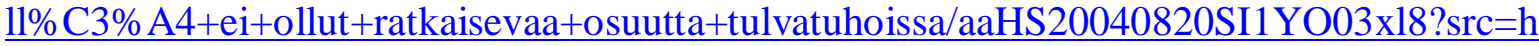
aku\&ref=arkisto\%2F (7.1.2016).

HS 16.10.2008 Uudet radiokalat kertovat lisää Vantaanjoesta ensi vuonna (New radio transmitters on fish will provide more information about Vantaa River next year) http://www.hs.fi/paivanlehti/arkisto/Uudet+radiokalat+kertovat+lis\%C3\%A4\%C3\%A4+Van taanjoesta+ensi+vuonna/aaHS20081016SI1KA03age?src=haku\&ref=arkisto\%2F (7.1.2016).

HS 20.7.2010 Joen kunto on vain tyydyttävä (State of the river is only moderate) http://www.hs.fi/paivanlehti/arkisto/Joen+kunto+on+vain+tyydytt\%C3\%A4v\%C3\%A4/aaH S20100720SI1KA01n8r?src=haku\&ref=arkisto\%2F (7.1.2016).

HS 13.8.2010 Vantaanjoen vesi on uimakelvotonta (Vantaa River unsuitable for swimming) http://www.hs.fi/paivanlehti/arkisto/Vantaanjoen+vesi+on+uimakelvotonta/aaHS20100813S I2KA02lzi?src=haku\&ref=arkisto\%2F (7.1.2016)

HS 14.8.2010 Vantaanjokeen pulahtaa nyt omalla vastuulla (Swimming in Vantaa River now at one's own risk) http://www.hs.fi/paivanlehti/arkisto/Vantaanjokeen+pulahtaa+nyt+omalla+vastuulla/aaHS20 100814SI1KA01x97?src=haku\&ref=arkisto\%2F (7.1.2016). 
HS 30.4.2011 Uudenmaan pisin jäteviemäri (The longest sewer in Uusimaa) http://www.hs.fi/paivanlehti/arkisto/Uudenmaan+pisin+j\%C3\%A4teviem\%C3\%A4ri/aaHS2 0110430SI1KA010h1?src=haku\&ref=arkisto\%2F (7.1.2016).

HS 20.11.2011 Vantaanjokeen valuvat jätevedet pannaan kuriin (Wastewater running into Vantaa River will be capped)

http://www.hs.fi/paivanlehti/arkisto/Vantaanjokeen+valuvat+j\%C3\% A4tevedet+pannaan+k uriin/aaHS20111120SI1KA01vkr?src=haku\&ref=arkisto\%2F (7.1.2016).

HS 14.10.2012 Vantaanjoen tahallinen pilaaminen on lopetettava (Willful damage to Vantaa River must be stopped) http://www.hs.fi/paivanlehti/\#mielipide/Vantaanjoen+tahallinen+pilaaminen+on+lopetettava /a1350113190922 (7.1.2016).

HS 28.4.2013 Jätevesi yhä Vantaan riesa (Wastewater still a nuisance to Vantaa River) http://www.hs.fi/paivanlehti/kaupunki/J\%C3\%A4tevesi+yh\%C3\% A4+Vantaan+riesa/a1367 033379395 ?src=haku\&ref=arkisto\%2F (7.1.2016).

HS 1.5.2013 Kevään tulvavedet eivät ole jätevettä (Spring floodwater is not wastewater) http://www.hs.fi/paivanlehti/mielipide/Kev\%C3\%A4\%C3\%A4n+tulvavedet+eiv\%C3\%A4t+ ole+j\%C3\%A4tevett\%C3\%A4/a1367291606998?src=haku\&ref=arkisto\%2F (7.1.2016).

HS 1.6.2014 Vantaanjoesta tuli kirjolohien joukkohauta (Vantaa River becomes mass grave of rainbow trouts) http://www.hs.fi/kotimaa/a1401587899301 (7.1.2016).

HS 16.2.2015 Kevättulvien aiheuttamat ongelmat on ratkaistu: Puhdistamoa laajennettiin riihimäkeläisten uloste ei enää likaa Vantaanjokea (Problems caused by summer flooding solved: WWTP amplified - feces from Riihimäki no longer pollute Vantaa River) http://www.hs.fi/kaupunki/a1423981910656 (7.1.2016).

HSY (2014). Vantaanjoen jätevesipäästöjen hallinta (Management of wastewater emissions to Vantaa River). MAKERA -hanke.

HSY \& VHVSY (2013). Vesilaitokset ja kalataloustoimijat virittävät yhteistyötä Vantaanjoen hyväksi (Water treatment organizations and fishing industry planning cooperation for improving Vantaa River ), bulletin 1.2.2013.

HU 6.2.2013 Vantaanjoen jätevuodot halutaan yhteistyöllä kuriin (Cooperation desired to stop wastewater flows into Vantaa River) http://www.helsinginuutiset.fi/artikkeli/221545vantaanjoen-jatevuodot-halutaan-yhteistyolla-kuriin (7.1.2016).

HU 25.7.2013 Vantaanjoki kärsii edelleen pahoin (Vantaa River still suffering badly) http://www.helsinginuutiset.fi/artikkeli/247313-vantaanjoki-karsii-edelleen-pahoin (7.1.2016).

Häikiö, L. \& Leino, H. (2014). Tulkitsevan politiikka-analyysin lähtökohdat (Principles of interpreting policy analysis). In: Tulkinnan mahti. Johdatus tulkitsevaan politiikkaanalyysiin. L. Häikiö \& H. Leino (ed.). Tampereen yliopistopaino oy - Juvenes Print, Tampere, Finland, pp. 9-30.

Jakku, E., Burch, D. \& Rickson, R. (2009). Constructing an environmental problem: claims-making in the Brisbane River dredging dispute. Australasian Journal of Environmental Management 16(1), 25-35.

Jones, S. (2002). Social constructionism and the environment: through the quagmire. Global Environmental Change 12(4), 247-251.

Krippendorff, K. \& Bock, M. (2009). The Content Analysis Reader. Sage Publications Inc., Thousand Oaks, CA, USA.

Laakkonen, S. (2001). Vesiensuojelun synty: Helsingin ja sen merialueen ympäristöhistoriaa 18781928 (The Origins of Water Protection in Helsinki in 1878-1928). Gaudeamus, Helsinki, Finland.

Lahti, K. (2014). Executive director of VHVSY, personal communication 9.6.2014.

Lahti, K. (2015). Executive director of VHVSY, personal communication, email 6.5.2015. 
Laine, M. \& Peltonen, L. (2003). Ympäristökysymys ja aseveliakseli: ympäristön politisoituminen Tampereella vuosina 1959-1995 (Environmental issues and the "Brothers-in-arms Axis": Politicization of the Environment in Tampere from 1959 to 1995). Tampere University Press, Tampere, Finland.

Lau, J., Butler, D. \& Schütze, M., (2002). Is combined sewer overflow spill frequency/volume a good indicator of receiving water-quality impact? Urban Water, 4(2), 181-189.

Mazzoleni, G. \& Schultz, W. (1999). "Mediatization" of politics: a challenge for democracy? Political Communication, 16(3), 247-261.

Metcalf \& Eddy, Inc. (2003). Wastewater Engineering: Treatment and Reuse, $4^{\text {th }}$ ed., revised by George Tchobanoglous, Franklin L. Burton, H. David Stensel, McGraw-Hill, New York, USA.

Mikola, E. \& Häikiö, L. (2014). Merkitysten muodostuminen politiikkaprosesseissa: päästökaupan kansalliset kamppailut ja tarinalinjat (Formulation of meanings in the political process: the national contests and storylines of emission trade) In: Tulkinnan mahti. Johdatus tulkitsevaan politiikka-analyysiin. L. Häikiö \& H. Leino (ed.). Tampereen yliopistopaino oy - Juvenes Print, Tampere, Finland, pp. 56-83.

Nie, L., Lindholm, O., Lindholm, G. \& Syversen, E. (2009). Impacts of climate change on urban drainage systems - a case study in Fredrikstad, Norway. Urban Water Journal, 6(4), 323332. DOI: $10.1080 / 15730620802600924$.

Pellizzoni, L. (2011). The politics of facts: local environmental conflicts and expertise, Environmental Politics, 20(6), 765-785. DOI: 10.1080/09644016.2011.617164.

Ragin, C. C. (1994). Constructing Social Research: The Unity and Diversity of Method. Pine Forge Press, Thousand Oaks, CA.

Raunio, J., Rinne, J. \& Holsti, H. (2009). Vantaanjoen yhteistarkkailu. Kalasto ja kalastus vuonna 2008 (Cooperative observation of the Vantaa River. Fish populations and fishing in year 2008), Kymijoen vesi ja ympäristö ry, Report 182/2009.

Raunio, J., Rinne, J. \& Holsti, H. (2011). Vantaanjoen yhteistarkkailu. Kalasto ja kalastus vuonna 2010 (Cooperative observation of the Vantaa River. Fish populations and fishing in year 2010), Kymijoen vesi ja ympäristö ry, Report 209/2011.

Saikkonen, P. (2015). Riskitieto kuntapäätöksenteossa. Tapauksena saastunut maaperä Helsingissä (Risk information in municipal decision-making. The case of polluted soil in Helsinki), Sosiaalitieteiden laitoksen julkaisuja 2015:9 Yhteiskuntapolitiikka, Helsingin yliopisto, Unigrafia, Helsinki

Saura, A., Könönen, K., Yrjölä, R. \& Rinne, J. (2005). Vantaanjoen yhteistarkkailu kalasto vuonna 2004 ja pohjaeläimet vuosina 2002-2004 (Cooperative observation of the Vantaa River. Fish populations in 2004 and benthos from year 2002 to 2004), Report Kala- ja riistaraportteja nro 368, Finnish Game and Fisheries Research Institute, Helsinki, Finland.

Schönach, P. (2015). Expanding of sanitary infrastructure shaping river history: River Vantaa (Finland) 1876-1982. Environment and History 21(2), 201-226.

Semadeni-Davies, A., Hernebring, C., Svensson, G. \& Gustafsson, L.-G. (2007). The impacts of climate change and urbanisation on drainage in Helsingborg, Sweden: Combined sewer system. Journal of Hydrology 350(1-2), 100-113. DOI: 10.1016/j.jhydrol.2007.05.028.

Stenholm, K. (2004). Kesän 2004 tulvan aiheuttamat kalakuolemat Vantaanjoella, sekä Riihimäen ja Hyvinkään alueen kalakuolemat yleensä (Fish die-offs in the Vantaa River caused by summer flooding in 2004, and fish die-offs in the Riihimäki and Hyvinkää regions in general), Virho. http://www.virtavesi.com/vanhatsivut/Vantaa/tulva104.pdf (7.1.2016).

Stenholm, K. (2006). Vantaanjoen jätevesipäästöt (Wastewater emissions to the Vantaa River), Virho. http://www.virtavesi.com/vanhatsivut/Vantaa/paasto06.htm. (7.1.2016)

Stenholm, K. (2008). Lausunto Vantaanjoen kalatalous ja pohjaeläintarkkailuohjelmasta 10.2.2008 (Statement on the observation program of the fishing industry and benthos in the Vantaa 
River on 10.2.2008) Virho. http://www.virtavesi.com/vanhatsivut/Vantaa/Vantaanjoenkt\%20ja_petarkohj2008.pdf (7.1.2016).

Stenholm, K. (2012). Muistutus Riihimäen jätevedenpuhdistamon ympäristölupapäätöksen lupamääräysten tarkistusasiaan (Reprimand for revision of the environmental permission requirements for the Riihimäki WWTP), Virho.

http://www.virtavesi.com/images/lisakuvat/Muistutus.pdf (7.1.2016).

Stenholm, K. (2013). Vantaanjoki vuonna 2012 (Vantaa River in 2012), Virho. http://virtavesi.com/images/lisakuvat/Vantaanjoki\%20vuonna\%202012\%20b.pdf (7.1.2016).

Stenholm, K. (2015). Asia: Virtavesien hoitoyhdistys ry:n mielipide Vantaanjoen vesistöalueen tulvariskien hallintasuunnitelmaan (Opinion of the Stream Care Association of the plan for flood risk management in the Vantaa River watershed), Virho. http://www.virtavesi.com/images/lisakuvat/Mielipide\%20Vantaanjoen\%20tulvasuojelu.pdf (7.1.2016).

Stenholm, K. \& Lehtinen, E. (2005). Vantaanjoen vaelluskalakannoilla on edelleen paljon ongelmia (Migrant fish populations in the Vantaa River still have many problems), Virho. http://www.virtavesi.com/vanhatsivut/Vantaa/tied0605.htm (7.1.2016).

Tibbetts, J. (2005). Combined sewer systems: down, dirty and out of date. Environmental Health Perspectives, 113(7), A464-A467.

Urho, A. (2011). Vantaanjoen valuma-alueen jätevesiylivuodot. Esiselvitys ja toimenpideohjelma (Wastewater overflow in the catchment area of the Vantaa River. Preliminary study and action program). Helsingin seudun ympäristöpalvelut, Helsinki, Finland.

Uusimaa Employment and Economic Development Center \& VHVSY (2004). Vantaanjoen kalatalousvahingoille ei korvauksia (No compensation for damage to fisheries in the Vantaa River), announcement 29.10.2004.

Vahtera, H., Männynsalo, J. \& Lahti, K. (2010). Vantaanjoen yhteistarkkailu. Vedenlaatu vuosina 2005-2009 (Cooperative observation of the Vantaa River. Water quality from 2005 to 2009), Report 64/2010, VHVSY, Helsinki, Finland.

Vahtera, H., Männynsalo, J. \& Lahti, K. (2014). Vantaanjoen yhteistarkkailu. Vedenlaatu vuosina 2011-2013 (Cooperative observation of the Vantaa River. Water quality from 2011 to 2013), Report 72/2014, VHVSY, Helsinki.

Vahtera, H., Männynsalo, J., Pasanen, R., Valtari, M. \& Lahti, K. (2008). Vantaanjoen yhteistarkkailu. Vedenlaatu vuonna 2007 (Cooperative observation of the Vantaa River. Water quality in year 2007), Report 61/2008, VHVSY, Helsinki, Finland.

Vahtera, H., Muukkonen, P., Männynsalo, J. \& Lahti, K. (2005). Vantaanjoen yhteistarkkailu. Vedenlaatu vuosina 2000-2004 (Cooperative observation of the Vantaa River. Water quality from 2000 to 2004), Report 56/2005, VHVSY, Helsinki, Finland.

Väliverronen, E. (1997). Mediat ympäristöpolitiikan areenana (Media as the arena of environmental politics). LTA 2(97), 186-192.

VS 23.9.2011 Mies joka haluaa pelastaa Vantaanjoen (The man who wants to save the Vantaa River) http://www.vantaansanomat.fi/artikkeli/71978-mies-joka-haluaa-pelastaa-vantaanjoen (29.1.2015).

VS 15.11.2012 HSY korjaa järjestelmiään - jätevuodot jatkuvat (HSY repairing its systems - waste flows continue) http://www.vantaansanomat.fi/artikkeli/181813-hsy-korjaa-jarjestelmiaan\%E2\%80\%93-jatevuodot-jatkuvat (29.1.2015).

Yearley, S. (2002). The social construction of environmental problems: a theoretical review and some not-very-Herculean labors. In: Sociological Theory and the Environment. Classical Foundations, Contemporary Insights. R. E. Dunlap, F. H. Buttel, P. Dickens \& A. Gijswijt (eds.). Rowman \& Littlefield Publishers, INC, Lanham, USA, pp. 274-285.

Yin, R. K. (2003). Case Study Research: Design and Methods. 3rd ed. Sage, Thousand Oaks, CA. 
Yle News 12.8.2004 Vantaanjoen kalakannasta puolet kuollut (Half of the fish population of the Vantaa River is dead) http://yle.fi/uutiset/vantaanjoen_kalakannasta_puolet_kuollut/5160966 (7.1.2016).

Yle News 14.8.2004 Vantaanjoen kalakuolemista korvausvaateita (Compensations demanded for fish die-offs in Vantaa River) http://yle.fi/uutiset/vantaanjoen_kalakuolemista_korvausvaateita/5161039 (7.1.2016).

Yle News 3.10.2009 Jätevesipäästöt häiritsevät kalojen kutua Vantaanjoessa (Wastewater emissions disrupting fish spawning in Vantaa River)

http://yle.fi/uutiset/jatevesipaastot_hairitsevat_kalojen_kutua_vantaanjoessa/1053419 (7.1.2016).

Yle News 12.7.2010 Kalanraadot haisevat Riihimäen Arolammilla (Fish carrion odor in Arolammi Pond of Riihimäki) http://yle.fi/uutiset/kalanraadot_haisevat_riihimaen_arolammilla/6161072 (7.1.2016).

Yle News 13.8.2010 Vantaanjoen veden laadusta erimielisyyttä (Disagreement on water quality of Vantaa River) http://yle.fi/uutiset/vantaanjoen veden laadusta erimielisyytta/5613635 (7.1.2016).

Yle 16.8.2010 Ympäristöministeri vaatii Vantaanjoen varren jätevesijärjestelmiä kuntoon (Minister of the Environment demands that wastewater systems of Vantaa River watershed be repaired)

http://yle.fi/uutiset/ymparistoministeri vaatii vantaanjoen varren jatevesijarjestelmia kunt oon/5614723 (7.1.2016).

Yle News 23.8.2010 Ympäristökeskus: Välttäkää Vantaanjoessa uimista (Regional Environment Center: Swimming in Vantaa River should be avoided) http://yle.fi/uutiset/ymparistokeskus_valttakaa_vantaanjoessa_uimista/5618552 (7.1.2016).

Yle News 27.8.2010 Päijänteen vettä ehdotetaan ratkaisuksi Vantaanjoen surkeuteen (Lake Päijänne water proposed as resolution to misery of Vantaa River) http://yle.fi/uutiset/paijanteen vetta ehdotetaan ratkaisuksi vantaanjoen surkeuteen/56213 $\underline{09}$ (7.1.2016).

Yle News 11.9.2010 Natura ei pelasta Vantaanjokea jätevesiltä (Natura will not save Vantaa River from wastewaters) http://yle.fi/uutiset/natura_ei_pelasta_vantaanjokea_jatevesilta/5630181 (7.1.2016)

Yle News 11.4.2011 Kevättulvat kuormittavat Vantaanjokea (Spring floods straining Vantaa River) http://yle.fi/uutiset/kevattulvat_kuormittavat_vantaanjokea/5340396 (7.1.2016).

Yle News 1.6.2011. Pikkukosken vesi taas uimakelpoista (Water in Pikkukoski again suitable for swimming) http://yle.fi/uutiset/pikkukosken_vesi_taas_uimakelpoista/5369570 (7.1.2016).

Yle News 27.6.2012 Helsinki patistaa Riihimäkeä viemäriremontteihin (Helsinki urging Riihimäki to renovate sewers) http://yle.fi/uutiset/helsinki_patistaa_riihimakea_viemariremontteihin/6195758 (7.1.2016).

Yle News 13.11.2012 Vantaanjoen jätevesikuormitus helpottanee (Wastewater loading to Vantaa River will probably be eased) http://yle.fi/uutiset/vantaanjoen jatevesikuormitus helpottanee/6375133 (7.1.2016).

Received 12 January 2016; accepted in revised form 22 April 2016. Available online 